\title{
Impact of Knowledge Management and Organisation Accomplishment - with Reference to College's in Chennai City
}

\author{
P. Libia, N. Swarnalatha, M. Jeevitha Kumari
}

\begin{abstract}
The concept of knowledge management in organization is a valuable instrument to improve the performance of organization. The aim of the paper is to examine the impact of knowledge through Creating, Accumulating, Organising and Utilising the knowledge management and Organisation accomplishment with reference to college's in Chennai city. The survey is conducted using well formulated questionnaire. Convenience sampling is applied for generating data. The researcher circulated 1000 questionnaire in 10 colleges in Chennai city. The researcher obtained 464 responses from the employees in various colleges. After scrutinizing the researcher indentified 48 of them are found with flaw. Hence the sample size of the responded is 416. Relevant statistical analytical techniques including Factor Analysis, Reliability and Regression Analysis were used. The result indicates that all three dimensions of knowledge management included Technical Knowledge; Cultural Knowledge and Human Knowledge have a positive and significant power to affect organizational accomplishment.
\end{abstract}

Keywords : Knowledge Management (KM), Organisation Accomplishment (OA), Technical Knowledge, Cultural Knowledge, Human Knowledge.

\section{INTRODUCTION}

Knowledge management is a process of creating, accumulating, and utilising knowledge to the optimum level which enhance organizational accomplishment. In the current scenario the education intuition need adequate knowledge updates to compete with both student fraternity and faculty development. The Excellency in college or universities will be possessed through effective KM said by (Muhammad et al., 2011) in his empirical study. We have analysis that the empirical research has been conducted by (Kalling, 2003; Zack, et al., 2009) have investigate the positive relationship between KM and Organisation Accomplishment.

The conceptual framework (L. A. Y. Al-Hakim 2011) prove that the KM factor have a positive relationship between Organisation Accomplishment which increases the success of the higher education in Chennai city. The KM have a direct benefit towards the growth and development of the higher education's, which further solidified with the advancement of technology and communication possessed said by ( Reynolds 2005).

Revised Manuscript Received on December 05, 2019.

* Correspondence Author

Dr .P. Libia*, DRBCCC Hindu College, Chennai, India. Email: plibia86@gmail.com

N. Swarnalatha, DRBCCC Hindu College, Chennai, India Email:goldencreeperns@gmail.com

M. Jeevitha Kumari, DRBCCC Hindu College, Chennai, India. Email: jeevithasheryl@gmail.com
It is referred from (Chen \& Burstein, 2006; Kebao \& Junxun, 2008; Muhammad et al., 2011) that the use of KM in higher education will lead to organisational achievements and technology updation in colleges and university in Chennai city. In the context, (Kidwell, Vander Linde and Johnson 2000) identified that the implementation of KM have a greater impact or benefits in higher-education environment like research process, curriculum development process, student development process, faculty enrichment process and alumni services process, academic and administrative services process and colleges and university development and strategic planning process. We have analysis that use of KM in higher education will have many direct benefits for organisational achievements.

The researcher identified from ground of research that KM contribute effectiveness and high efficiency in educational field to update the technical and technological outcomes, the Recent studies of (Moon \& Lee, 2014) have concluded that culture and knowledge-sharing processes contribute effective growth and development in organisational performance in the colleges in Chennai city. It is observed from (Bhatt, 2001) $\mathrm{KM}$ is not just sharing of information but interaction between the faculty to student, from student to faculty, form technologies and techniques and teaching aid and practice in the environment and society.

\section{REVIEW OF LITERATURE}

This study is intended to examine the level of knowledge management and organizational accomplishment among expert, faculties and students in the selected colleges in Chennai city. The researcher received data in and around the colleges in Chennai city.

Martin (2005) the scholar over viewed concept given by martin analysed that KM and organisational accomplishment is interrelated and have a mutual relationship in the growth of higher education. Still debating the concepts and definitions related to knowledge management.

Kalling, (2003); Zack, et al., (2009) the researcher investigated and identified that there is a positive relationship between KM and performance in education context. Sallis and Jones (2002) this study emphasized the need for KM in education and organisation accomplishment, since there is technical and technological advancement is worldwide. In this comparative world excellent achievements are achieved in one area of the colleges or universities only when they process KM factor.

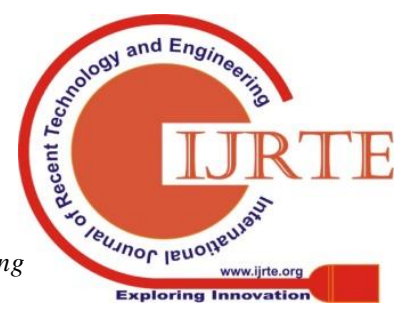


Aljanabi (2007), according to this review KM in higher education is still a new concept, the higher-education sector responds positively to $\mathrm{KM}$ practices in both institution level and individual level.

Amin (2006), the researcher profound the emerging changes in higher education and universities since because of competitive in education, Meanwhile, educational markets are becoming global. Based on this fact, ability to compete and stay in business under such a condition depends in our modern world popularly referred to KM. The knowledge management grab the information from key source which help to demotivate the unconditional environment in higher education. The problem today is not how to find the information, but how to manage it; the most important challenge for colleges and university to how to process knowledge and to make it profitable in the recent knowledge-driven organization.

Sallis \& Jones, (2002) it can be found that the use of KM in higher education will have many direct benefits for organisational accomplishment. However in current scenario $\mathrm{KM}$ has been applied in every universities and colleges in Chennai city.

\section{OBJECTIVE IN STUDY}

1. To study the predominant factors of knowledge management through Creating, Accumulating, Organising and utilising the knowledge in Higher Education

2. To analysis the empirically influence of all three dimensions of knowledge management included Technical Knowledge; Cultural Knowledge; Human Knowledge in Higher Education

3. To identify the impact of knowledge management on organizational accomplishment

\section{METHODOLOGY}

The study is based on both primary and secondary data. The primary data is collected on structured questioner with optional type question as well as statement in likert's 5 point scale.

Reliability: The Researcher conducted research analysis to check the statement and variables in the present research. Cronbach alpha method is applied on the variable of knowledge management and organisation accomplishment and the value obtained are 0.870 and 0.779 respectively, it show that the research instrument used in the research is highly reliable and the research instrument as be used further to verify the objective and test the hypothesis .

Validity: After conducted reliability test the researcher conducted the validity test in the following sets

1. Face validity

2. Content validity

\section{Discernment validity}

Face Validity: Face validity is done during pre-test stage through interaction with Student's, Expert and Faculties in different organisation they clearly expressed the motions about the research instrument and some sentence were

modified and corrected.

Content Validity: Content validity is done through the polite survey and the respondent expressed their opinion though questioner circulated this shows that the respondent total variance is found to be very high and content are matched for the research work.

Discernment Validity: Discernment validity is done through the main study and application of factor analysis, factor segmentation is found to proper with high total variance therefore the research instrument passed the validity test.

\section{DATA COLLECTION}

The researcher applied convenient sampling method to collect the responses from faculties and students of various colleges in Chennai city. The researchers consider top ten colleges in Chennai city for data collection purpose. The researcher circulated 1000 each in all the ten colleges and able to obtain 464 responses with completed responses. After scrutinising 48 of the questioner are fill with flaws hence the researcher reject those response and consider remaining 416 responses for the research. Hence the sample size of research is 416 .

\section{Data Analysis}

After entering the coding of the questioner the researcher analysis using both univariate and multivariate statistical techniques. Factor analysis along with KMO and Bartlett test suggested exploited to measure the factor of Organisation Accomplishment College's in Chennai city. Chi-squire test for sphericity is applied to test the normality of the data as well as the distribution of the sample unit.

\section{ANALYSIS AND DISCUSSION}

This deals with projections of result arrived at from the statistical analysis and general discussions with the regard to the result of Organisation Accomplishment College's in Chennai city.

Table- 1: Showing the Mean, Standard Deviation of the Samples in Organisation Accomplishment

\begin{tabular}{|c|l|c|c|c|c|}
\hline S.No & Group & $\begin{array}{c}\text { KM } \\
\text { Mean }\end{array}$ & $\begin{array}{c}\text { Stability } \\
\text { SD }\end{array}$ & $\begin{array}{c}\text { Creativity } \\
\text { Mean }\end{array}$ & $\begin{array}{c}\text { Stability } \\
\text { SD }\end{array}$ \\
\hline 1 & $\begin{array}{l}\text { Group as } \\
\text { total }\end{array}$ & 87.97 & 13.78 & 33.91 & 7.53 \\
\hline 3 & $\begin{array}{l}\text { Experience } \\
\text { above 5 } \\
\text { years }\end{array}$ & 85.13 & 16.51 & 27.88 & 7.85 \\
\hline 4 & $\begin{array}{l}\text { Experience } \\
\text { below 5 } \\
\text { years }\end{array}$ & 88.92 & 12.60 & 35.92 & 6.24 \\
\hline 5 & $\begin{array}{l}\text { Accomplish } \\
\text { avent below } \\
\text { average }\end{array}$ & 89.38 & 13.59 & 34.63 & 11.26 \\
\hline $\begin{array}{l}\text { Accomplish } \\
\text { avent above }\end{array}$ & 71.00 & 20.01 & 32.00 & 6.28 \\
\hline
\end{tabular}


From the above table the mean value of KM stability for the overall group shows 87.97 which we can state that the level of KM stability for the overall group is average.

The mean value of the creative stability of the employees Accomplishment for the overall of group show 33.91 hence we can interpret the creativity level for the employees Accomplishment for the overall group is low .

Table -2: Showing the relationship between KM stability and creativity

\begin{tabular}{|c|c|c|c|c|}
\hline Variable & N & Mean & SD & r-value \\
\hline KM stability & 32 & 87.97 & 13.78 & \\
Creativity & 32 & 33.91 & 7.53 & $0.033^{*}$ \\
\hline
\end{tabular}

*= significant at 0.05 level

From the above table the ' $r$ ' value of 0.033 indicates the positive correlation and we can infer that Knowledge Management have a positive and significant power to affect organizational accomplishment.

\section{FINDINGS AND CONCLUSION}

This paper contributes the value of knowledge management in the higher education. The study indicates the positive and significant relationship between the KM and organizational accomplishment. It is found that the influence of all three dimensions of knowledge management included Technical Knowledge; Cultural Knowledge; Human Knowledge in Higher Education. The researcher concluded that the requirement effective influence of knowledge management in the colleges and university is necessary since to have a positive relationship and to sustainability in the growth of organisational accomplishment.

\section{REFERENCES}

1. Martin, B. (2005). Information society revisited: from vision to reality. Journal of Information Science, 31(1), 4-12.

2. Kalling, T (2003). Knowledge management and the occasional links with performance Journal of Knowledge Management, 7(3), 67-81.

3. Amin, N. W. G. (2006). Higher education in Sudan and knowledge management applications IEEE explorer, 60-65.

4. Aljanabi, F. L. (2007). The role of knowledge management processes in the formulation of the strategic vision: A survey at the Universities of Baghdad and Mustansiriya Unpublished Master thesis, University of Mustansiriya, Iraq.

5. Kidwell, J. J., Vander Linde, K. M., \& Johnson, S. L. (2000). Applying corporate knowledge management practices applying corporate in higher education. Educause Quarterly(4), 28-33.

6. Lee, K. C., Lee, S., \& Kang, I. W. (2005). KMPI: measuring knowledge management performance. Information \& Management, 42, 469-482.

7. Sallis, E., \& Jones, G. (2002). Knowledge management in education: Enhancing learning \& education. London, UK: Kogan Page Ltd

\section{AUTHORS PROFILE}

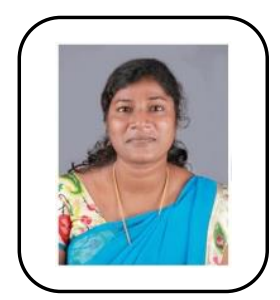

Dr. P. LIBIA Assistant Professor DRBCCC Hindu College and completed $\mathrm{PhD}$ in Vels University in October 2017. I have published 4 Scopus Indexed Journal, 6 Googol Scholar Indexed Journal, 5 Indexed Journal, participated 4 International conference International conference on Native economy, commerce and trade ( Topicworking capital management, March 2016 ) Bhaktavatsalam Memorial college for women korattur, International conference on contemporary issues and challenges in commerce and management (Topic- Risk management in bank, Feb 2015) - Sri Ganesh college of Arts \&Science, International conference on "Emerging trends in business paradigm" (Topic- stress management ) - Jaya college of arts and science, participated 3 National conference National conference on strategies for sustainable development practice in Indian industries (Topicsustainable development practices in banking sectors Feb 2015) - Sri kaliswari college, National conference on emerging trends in knowledge management ( knowledge management Sep 2016) - Vels university, National conference on recent advancements in business practices (working capital management Feb 2016) - Nehru institute of management studies.

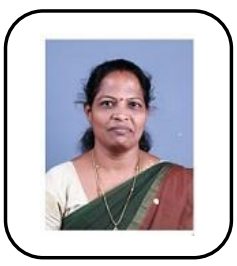

Dr. N.Swarnalatha Assistant Professor \& Head Department Corporate Secretaryship No. of articles/papers published in Seminars/ Conferences/Journals. No. of articles/papers in Journals International: 01 National: 01. No. of papers presented in Seminars / Conferences International: 07 National: 04 State:02 No. of articles published in Books / Conference Proceedings :01 Workshops Organised:5.

M.Jeevithakumari is an Assistant Professor of Commerce. Participated State level workshop on self discovery and self embracement on 7 th to 11 th

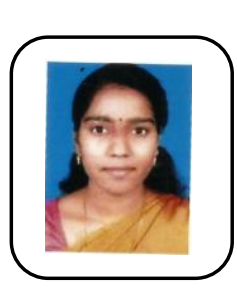
January 2006 at Loyola College. Inter-collegiate symposium- logistics and its future potential in India on 1st and 2nd February 2006 at Loyola College. National Conference on Indian banking challenges in the past liberalization era on 18th and 19th January 2007 at Loyola college. Workshop on research methodology from 19th July to 21st July 2006 at Loyola College. Faculty development programme from 03.06.2015 to 04.06.2015 at D.R.B.C.C.C. Hindu College. IQAC UGC sponsored a 3day workshop on "The Application of SPSS for Data Analysis" from 19th to 21 sr January at Loyola College. Workshop on "Current Trends in Commerce Education" by D.R.B.C.C.C. Hindu College on 12th December 2015.Workshop on "Current Trends in Commerce Education" by D.R.B.C.C.C. Hindu College on 12th December 2011. 